DEVELOPING ENGLISH SPEAKING MATERIALS FOR STUDENTS OF OFFICE ADMINISTRATIONPROGRAM OF VOCATIONAL SCHOOL

\begin{abstract}
AN ARTICLE
Submitted in Partial Fulfillmentof the Requirements for the Degree of SarjanaPendidikan
\end{abstract}

By:

DUMORA MALINA SIJABAT

Registration Number: 2133121026

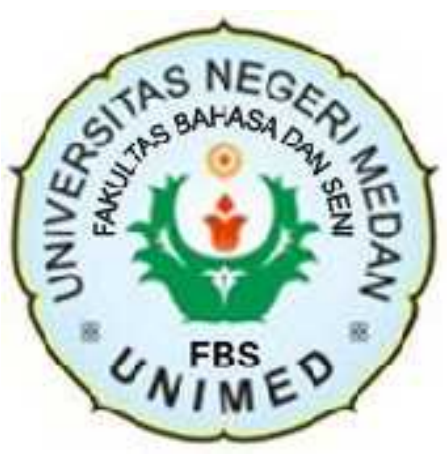

ENGLISH AND LITERATURE DEPARTMENT

FACULTY OF LANGUAGES AND ARTS

STATE UNIVERSITY OF MEDAN

2018 
ARTIKEL.

\section{DEVELOPING ENGLISH SPEAKING MATERIALS FOR STUDENTS OF OFFICE ADMINISTRATION PROGRAM OF VOCATIONAL SCHOOL}

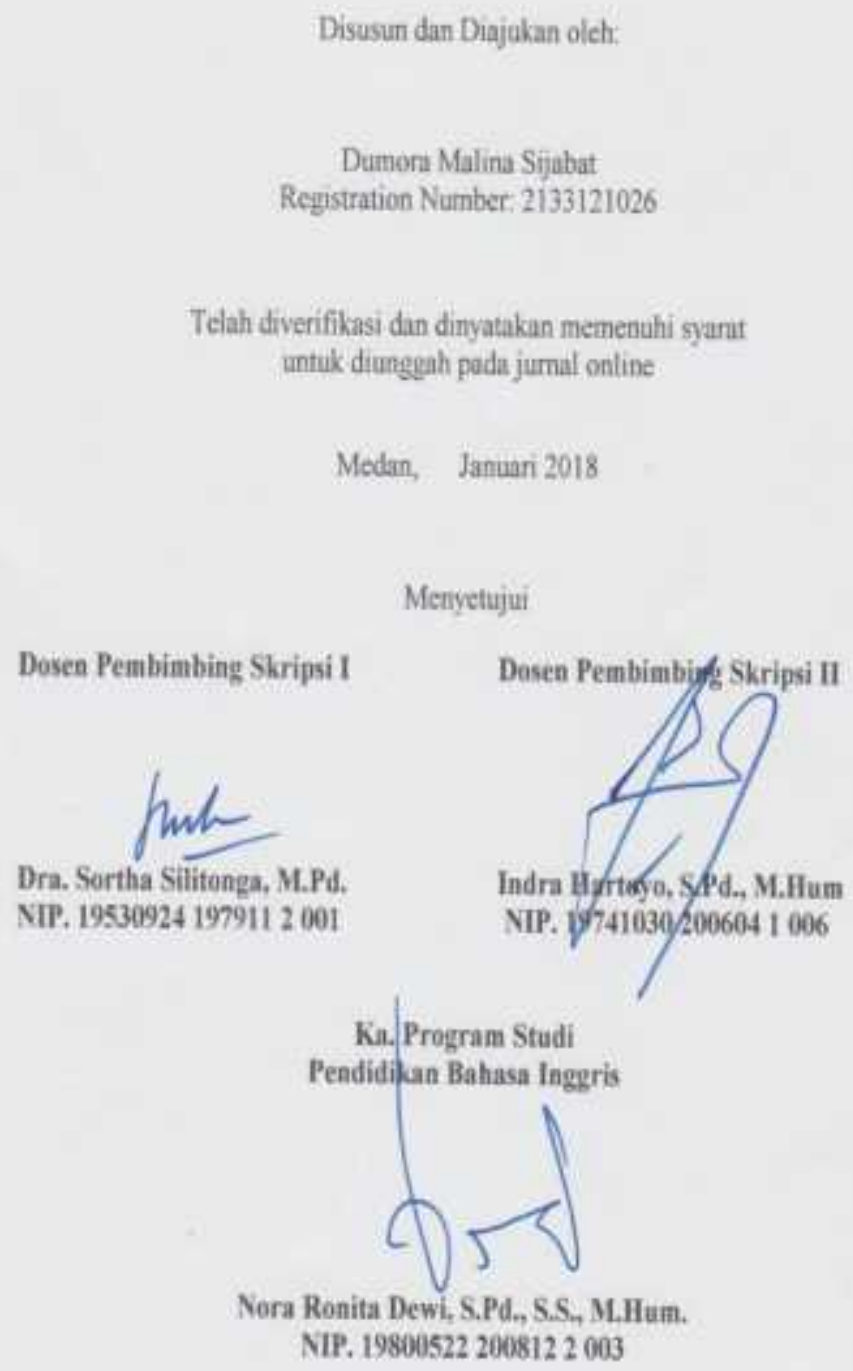




\title{
DEVELOPING ENGLISH SPEAKING MATERIALS FOR STUDENTS OF OFFICE ADMINISTRATION PROGRAM OF VOCATIONAL SCHOOL
}

\author{
*Dumora Malina Sijabat \\ **Sortha Silitonga \\ ** Indra Hartoyo
}

\begin{abstract}
Sijabat, Dumora. Registration Number: 2133121026. Developing English Speaking Materials for Students of Office Administration Program at Vocational School. A Thesis. English Education Study Program, State University of Medan, 2018

The objective of this study was to develop English speaking materials based on students' needs. This study followed the steps of research and development proposed by Borg and Gall, which are 1) need analysis; 2) planning(writing syllabus); 3) designing materials; 4) material evaluation; 5) revising (writing final product). It was found that $82.85 \%$ students agreed that the existing materials currently used by the students were irrelevant with office administration program. The more relevant materials were then developed based on scientific approach and relevant with their study program and work life situation. The learning materials were developed into 3 units of speaking materials. The learning materials were then validated by two experts. The average score of the validation was 85 . It showed that the developed learning materials were very good, relevant and feasible.
\end{abstract}

Keywords:English Speaking Materials, Scientific Approach, Research and Development

\footnotetext{
*Graduate

** Lecturer
} 


\section{INTRODUCTION}

\section{Background of the Study}

In the era of globalization, English as a second and international language is very important to learn because people need English to communicate to others from many different countries especially for students. English as a foreign language, students have to know well four basic skills namely listening, reading, speaking, and writing.

In Indonesia English has been used as a foreign language. English is consists of four skills which have to be mastered by the students, they are listening, speaking, reading and writing. Among the four language skills, reading is one of skill that should be learned well by the students because by having reading skill they will be easy to get information, knowledge, and science.

Vocational High Schools -SMK- are designed to prepare the students to work right after they graduate. The fresh graduate students of SMK are expected to master the skills of their expertise. Besides, English becomes very important since most of the job vacancies put English proficiency, both written and spoken, as one of the requirements.As the main focus of this research is in Office Administration program, this study program needs English primary in communication skill for daily conversation related to the office context.

One of the ways to help the Office Administration students in encouraging their speaking skill is through providing learning materials. Allwright in Ampa, et al (2013) argues that learning materials should teach students to learn, that they should be resource books for ideas and activities for learning, and that they should give teachers rationales for what they do. Learning materials are also used to help 
transfer information and skills to others. These are used in teaching at places like schools, colleges and universities. These can include textbooks, films, audios, and more or these can include printed and non-printed materials. The common characteristic of all of them is that they should enhance teaching in a meaningful, interesting way.

In order to develop learning materials for specific purposes for SMK students, one thing that should become the starting point is the learners' need. Hutchinson and Waters (1987) define ESP is an approach to language learning, which is based on learner need. ESP, then, is an approach to language teaching in which all decisions as to content and method are based on the learner's reason for learning. The new Curriculum is called Curriculum 2013 which uses the scientific approach as the basis in the teaching and learning process. However, in Curriculum 2013, it is found that vocational high schools and general high schools have the same English learning materials, even they use the same book.

Based on the researcher's observation which was done toward Office Administration students in SMK Jambi Medan on the $3^{\text {rd }}$ of May 2017, the researcher found that the material used in teaching-learning process is the same as the material for senior high school students which used the English book of Curriculum 2013. It means that SMK students do not have specific book of English whereas they have different needs with senior high school student in general. The textbook that students used didn't provide the relevant speaking learning material. It can be seen by student's handbook that government distributed for the school. They use "Bahasa Inggris" by Kementerian Pendidikan dan Kebudayaan, 2014. In terms of content, the topics and the conversations used 
were still irrelevant to the basic competence that the students are expected to be able to express the meaning of transactional conversation and the meaning of the text in oral related to the office context to be applied. The conversations used in this textbook were not suitable to their needs.

In order to support their learning activities, the students have to be taught English as the medium to explore English proficiency in learning activities within classroom and communicate with each other and must be trained to speak English in their daily communication. But in fact, the researcher found that their speaking didn't reach the competency because the students were not good in speaking English to express and even to understand the transactional conversation and text in the book, lack of English vocabularies, lack of practice, and fear of making mistakes.

\section{REVIEW OF LITERATURE}

Kayi (2006) said that speaking is a crucial part of second language learning and teaching. Moreover, Chaney in Kayi (2006) defines speaking as the process of building and sharing meaning through using verbal andnon verbal symbols in a variety of contexts. Speaking is one of four macro skills necessary for effective communication in any language, particularly when speakers are not using their mother tongue. As English is universally used as a means of communication, especially in the internet world, English speaking skills should be developed along with the other skills so that these integrated skills will enhance communication achievement both with native speakers of English and other members of the international community (Kamonpan, 2013). 
Materials are very crucial when English teaching and learning. Throug, materials, students can expand their knowledge of the use of language and it can help students to expose themselves to language. Tomlinson (2008:15) argues that materials are effective to help learners to notice features of the authentic language as they are exposed to facilitate and accelerate language acquisition. Hence, materials should provide exposure to authentic use of English through spoken and written texts with the potential to engage the learners cognitively and effectively.

\section{RESEARCH METHODOLOGY}

\section{Research Design}

This research was classified into an Educational Research and Development (R\&D). Educational R \& D was adapted from industry-based development model in which the results of the research will be taken to create new product or procedures, which then are systematically implemented, evaluated, and revised to meet specified criteria of effectiveness, quality, or similar standards (Gall, Gall, and Borg, 2003:569). Actually, the model should be simplified in this research. The ten stages of R\&D were simplified into six stages because it depend on the research needed, those are : 1)Need analysis, 2)Planning (writing the syllabus), 3) Designing the materials, 4) Material Evaluation, 5)Revising (writing the final product).

\section{Research Subject}

The subject of the research was the grade ten students of Office Administration program in SMK Jambi Medan and the teacher of Office Administration in SMK Jambi Medan. 


\section{Instruments of data collection}

There were two types of data in this research. They were qualitative and quantitative data. The qualitative data were obtained from the interviewsession with the teacher. As the result, there were opinions and suggestions from the SMK teacher about what the appropriate materials should be and the target needs and the match of the existing materials to core competence and basic competence of curriculum.

Furthermore, there were also quantitative data obtainedfrom questionnaire. The data of need analysis questionnaire was analyzed using frequencies and percentages. The highest percentages of the answers of each question will be considered to represent the students' needs. The percentage was calculated by dividing the frequency by the total of the respondents and then the result was multiplied by $100 \%$.

\section{Techniques of Data Analysis}

The questionnaires from students and experts judgments were analyzed by calculating the frequency of optional item to get what materials that the students needs and to evaluate the materials.

\section{DATA ANALYSIS AND MATERIAL DEVELOPMENT}

1. Need analysis: The main point that was found in this research was related to the materials. The instruments of this research were questionnaire, interview, and documents. The need analysis was conducted on September, $14^{\text {th }}$ and $15^{\text {th }}, 2017$ by distributing the need analysis questionnaire to grade ten students of Office Administration program at SMK Jambi Medan. 
2. Planning (writing the syllabus): The next step is writing the syllabus after need analysis was conducted.

3. Designing the materials: The designed materials consist of 3 units. Each unit consists of 5 parts; Observing, Questioning, Exploring, Associating, and Communicating. Unit one consists of 9 tasks, unit two consists of 8 tasks and unit three consists of 11 tasks. The titles of each unit were "Great Job!", "Showing Care/Sympathy", and "Congratulation on Your Promotion". Observing (Let's start) section provides activities to brainstorm the prior knowledge of the students about a topic that is given in the tasks, fulfill their curiosity so that they know the meaning of what they are going to learn, and to help students to find the fact about the relation between objects they are going to analyze. In this section, the students will have a picture and questions to lead them to the topic which is going to be learned. Questioning section consists of task which is used to encourage and inspire students to be active in learning process even develop some questions related to the topic. Exploring section provides activities to build their vocabulary in order to add new words for students and help them to translate the conversation tasks (let's role-play) and to help students so that they have competence in communicate good pronunciation. Associating (let's study) section provides the students are given deeper information and tasks related to the topic. And the last section is Communicating (let's practice). In this section, students will practice what they have learned.This section forces the students a lot to speak. After practicing, the studentswill have reflection section which content of some statement to measure thestudents' achievement in learning the topic. In 
the last there will be glossary.In addition, in the middle page of each unit, there will be "do you know?" sectionwhich gives the students' information related to office.

4. Material Evaluation: After the first draft of the materials was developed, the material were evaluated by the experts to know if it had been suitable or not. The material evaluation had been relevant with the standard of material evaluation proposed by BNSP. There are 20 questions distributed to the expert that covered four aspects of material evaluation proposed by BNSP; the appropriateness of the content, the appropriateness of the presentation, the appropriateness of the language, and the appropriateness of layout. The expert gave feedbacks to the first draft that needed to revise before getting the final draft of materials. The final score of the four aspects in the draft was 4.25 , validated by the first expert and 4.35 by the second expert which was categorized as "good" based on the interval $3.25 \leq \mathrm{x} \leq 4.5$.

5. Revising (writing the final product):After getting feedback from the experts, the speaking materials were revised and written into the final draft.

\section{CONCLUSION AND SUGGESTIONS}

\section{The Conclusion}

After analyzing the data, the conclusions are drawn as the following;

1. The existing English speaking materials are too general with the needs of Office Administration students. In term topics, they are not suitable with Office Administration which is make the students are lack of motivation because get difficult and confuse in learning English. 
2. Students of Office Administration needs speaking materials which are suitable with their major where the contents used in the course book are relevant and useful in the work situation. There are three units that developed in speaking materials for grade ten students of Office Administration, they are: Complimenting others, Showing care/sympathy, and Congratulating on Your Promotion. The designs of the speaking materials are based on scientific approach.

\section{The Suggestions}

There are three suggestions that the researcher gives, they are:

1. It is suggested that the newly developed materials should be used by the English teacher to encourage students of Office Administration to do the speaking activities in teaching and learning process that related to their major. It is important to build students' confidence first to speak because it will influence the teaching and learning process in the class.

2. It is expected to other researchers to develop English speaking materials for other grades and programs which have the problems with the availability of suitable English speaking materials.

\section{REFERENCES}

Ampa, Andi,et al. 2013. The Students' Needs in Developing Learning Materials for Speaking Skills in Indonesia. Journal of Education and Practice. 4(7)

Boonkit, Kamonpan. 2010. Enhancing the development of speaking skills for nonnative speakers of English. Procedia Social and Behavioral Sciences 2, 1305-1309.

Gall, M. D., Gall, J.P., and Borg. Walter. R. 2003. Educational Research: An Introduction. New York: Longman. 
Hutchinson, T. and Waters, A. 1987. English for Specific Purpose. Cambridge: Cambridge University Press.

Kayi. 2006. Teaching Speaking: Activities to Promote Speaking in a Second Language.The Internet TESL Journal. 12(11).

Tomlinson.2008. English Language Learning Materials. London: Continuum. 